\section{Self-esteem and depression levels in diabetes mellitus patients}

\author{
Yulianto, ${ }^{1}$ Yufi Aris Lestari, ${ }^{1}$ \\ Hartin Suidah, ${ }^{2}$ Anik Supriani, ${ }^{1}$ \\ Riska Aprilia, ${ }^{1}$ Bety Mayasari, ${ }^{1}$ \\ Dian Fitra Arismawati ${ }^{1}$
}

${ }^{1}$ School of Health Science, Dian Husada

Mojokerto; ${ }^{2}$ Nursing Academy of Dian

Husada Mojokerto, Indonesia

\begin{abstract}
This study aimed to identify the relationship between self-esteem and the level of depression in people with Diabetes Mellitus. Cross sectional design was used in the study. There were 48 respondents chosen by Simple Random Sampling technique. The instrument used was a questionnaire and then data was analyzed by Pearson test with a significance level of $\alpha 0.05$. The results showed that more than half of respondents had mild depression of 33 people $(68.8 \%)$. In addition, there is a relationship of self-esteem with the level of depression which based on the results of the Spearman Rho statistical test with the Significant value $\mathrm{p}=0.014<\alpha 0.05$. It is expected that health care professionals can provide support and motivate diabetic patients to maintain their daily activities.
\end{abstract}

\section{Introduction}

Diabetic patients who have complications are at risk to have mental health issues. Depression is a feeling of sadness and pessimism about life. Diabetic patients experienced a lot of complaints about illnesses, felt anxious with the prolonged treatments, as well as financial issues. According to World Health Organization, the number of diabetes mellitus patients in Indonesia will increase from 8.4 million in 2000 to around 21.3 million in 2030. In Indonesia, the prevalence of diabetes in 2013 reached 5.7 percent, namely around 8.5 million people. ${ }^{1}$ Indonesia ranked 7 th as the country with the highest number of diabetes cases in the world. Lifestyle factors are one of risk factors causing diabetes. The Indonesian Ministry of Health takes various steps to reduce diabetes, one of which is through the Minister of Health Regulation No.30 of 2013. A report from the Health Research and Development Agency of the Ministry of
Health, ${ }^{2}$ states that there is an increase in prevalence in patients with diabetes mellitus obtained based on an interview, namely $1.1 \%$ in 2007 to $1.5 \%$ in 2013 . Diabetes mellitus in 2009 to 2010 was ranked fifth in the most diseases in East Java after influenza, diarrhea, hypertension and typhus at $3.66 \%$ in 2009 and $3.61 \%$ in the Health Service Year (2010). Whereas in the survey on October 31, 2014, the data was obtained from the Head of the Village as many as 109 or as many as $12 \%$ of people affected by Diabetes Militus in the Larangan Hamlet, Krikilan Village, Kec. Driyorejo Kab. Gresik.

Diabetic patient felt embarrassed when interacting with others because of the injuries they suffered, the feeling of boredom must take medication every day, it was difficult to go on a diet according to the recommended and the patient always asked about the cure during treatment, so the patient had trouble sleeping because he always remembered the disease, the patient feels weak, likes to daydream, afraid and bored with his life which is always limited, the patient feels sad, anxious, hopeless because he is unable to move as usual (earning a living), and the patient feels an added burden on his family. ${ }^{3}$

Efforts to overcome patients with depression are by creating a therapeutic environment, creating a pleasant environment, activating patients in various activities and motivating their actions, motivating patients to overcome problems, improving health status and increasing their self-esteem which can be expressed in positive attitudes. ${ }^{4}$

\section{Materials and Methods}

Cross sectional study was used in the study. There were 48 respondents chosen by Simple Random Sampling technique. In this study the first instrument used was a questionnaire about self-esteem in patients with mellitus as many as 10 questions consisting of positive and negative statements. While the second instrument is a questionnaire according to Beck's inventory of the level of depression in diabetics with 13 questions.

Data collection begins with the home visits of respondents with initial population data collection consisting of name, age, sex, education, occupation and research observers about self-esteem and the level of depression, then collecting data for respondents with the questionnaire guidelines that have been made. Respondents were asked to answer the
Correspondence: Yufi Aris Lestari, School of Health Science Dian Husada Mojokerto, Mojokerto, Jalan Raya Gemekan No. 77, Gemekan Mojokerto Jawa Timur 61361, Indonesia.

Tel.: +62.321.327770 - Fax: +62.321 .327770$

E-mail: yufiarislestari@gmail.com

Key words: self-esteem, level of depression, diabetes mellitus.

Acknowledgements: the authors would like to thank all the respondents who voluntered for this study.

Contributions: the authors contributed equally

Conflict of interests: the authors declare no potential conflict of interest.

Funding: none.

Clinical trials: the study is not involved any clinical trials.

Conference presentation: part of this paper was presented at the $3^{\text {rd }}$ International Symposium of Public Health, 2018 October 31 - November 1, Universitas Airlangga, Surabaya, Indonesia

Dedication: the article is dedicated to School of Health Science Dian Husada Mojokerto.

Received for publication: 28 July 2019.

Revision received: 9 September 2019.

Accepted for publication: 15 October 2019.

This work is licensed under a Creative Commons Attribution NonCommercial 4.0 License (CC BY-NC 4.0).

(C) Copyright: the Author(s), 2019

Licensee PAGEPress, Italy

Journal of Public Health in Africa 2019; 10(s1):1200 doi:10.4081/jphia.2019.1200

researchers' questions which were in accordance with the questionnaire. The questionnaire was answered by respondents in the respondent's house. Questionnaires that were answered by the respondent were examined for completeness, if not complete the respondent was asked to complete it and then collected again.

\section{Results}

\section{General data}

Characteristics of respondents by age, gender, education, marital status,occupation/activities

Based on the Table 1, half of the respondents aged $>35$ years $(50 \%)$, one 
third were female $(33.8 \%)$, almost half of the respondents had elementary schools $(37.5 \%)$, most respondents were married $(83.3 \%)$ and one third of respondents were housewives/jobless $(37.5 \%)$.

\section{Special characteristics}

Characteristics of respondents based on self-esteem

Based on the Table 2, it shows that more than half of respondents' had high selfesteem $(60.4 \%)$. The average value of respondents' self-esteem was 29.52 with a minimum value of 13 and a minimum of 36 achieved the standard deviation of 6.157 .

\section{Characteristics of respondents based on depression level}

Based on the Table 3, more than half of respondents had a mild depression $(68.8 \%)$. Meanwhile the average value of the depression level of respondents is 9.71 with a minimum value of 4 and a maximum of 30 reaches the standard deviation of 7.512.

\section{Relationship of self-esteem with depression level}

From Figure 1, it can be seen that $y$ tends to enlarge when $\mathrm{x}$ enlarges, so the correlation is called a positive correlation between self-esteem and the level of depression, the relationship of self-esteem with the level of depression in diabetes mellitus patients shows a significance value of 0.036 which indicates that the correlation between self-esteem and depression level is a significant correlation value of 0.092 shows that the correlation is very strong. with the average value obtained that the mean value of the respondent's self-esteem was 29.52 with a minimum value of 13 and a minimum of 36 achieved the standard deviation of 6.157. The mean value of the depression level of respondents was 9.71 with a minimum value of 4 and a maximum of 30 achieved the standard deviation of 7.512. To determine the type of test then the normality test for each variable is carried out, from the results of the normality test for self-esteem variables obtained the significance value of 0.036 because the value of $p$ value: $<0.05$ in the variable selfesteem can be concluded that the data is not normally distributed.

\section{Discussion}

\section{Self-esteem}

The high self-esteem respondents characteristized by a useful person, at least as other people, have a number of good qualities, are able to do things as good as most others do and have a positive attitude towards themselves and others. Basically a person's self-esteem can be influenced by several factors including age, education, work.

In terms of age, it is known that most of the respondents age $>35$ years. At this age someone is mature enough to think and act, and respond to all things related to life. From the results of the study, it was found that respondents aged $>35$ years mostly had high self-esteem as much as $58.3 \%$. Individual's self-esteem changes according

to his age. ${ }^{5}$ Judging from the age of the respondents, it appears that most respondents within the productive age group (20 - 35 years). Productive age is the age at which a person reaches the level of productivity both in rational and motoric forms. In theory it is said that a person will experience a phase of change both psychologically and psychologically, related to his self-esteem. The older a person will be more mature and understand about life so that it has become a natural law

Table 1. Distribution of Frequency of Respondents by Age, Gender, Education, Marital status, occupation at Larangan Hamlet, Krikilan Village, Kec. Driyorejo Kab. Gresik.

\begin{tabular}{llcc} 
No & Variables & Frequency & $(\%)$ \\
\hline 1 & Age & & \\
2 & $<20$ years old & 5 & 10.4 \\
\hline 3 & $20-35$ years old & 19 & 39.6 \\
\hline Gender & $>35$ years old & 24 & 50 \\
1 & & & \\
2 & Male & 15 & 31.3 \\
\hline Education & Female & 33 & 68.8 \\
\hline 1 & & & \\
2 & No formal education & 8 & 16.7 \\
\hline 3 & Elementary school & 18 & 37.5 \\
\hline 4 & Junior high school & 6 & 12.5 \\
\hline 5 & Senior high school & 8 & 16.7 \\
\hline Marital Status & University & 8 & 16.7 \\
\hline 1 & & & \\
2 & Married & 40 & 83.3 \\
\hline 3 & Not married & 4 & 8.3 \\
\hline Occupation/Activities & 4 & 8.3 \\
\hline 1 & Divorced & & 31.3 \\
2 & Government employees & 4 & 22.9 \\
\hline 3 & Privat employees & 15 & 37.5 \\
\hline & Entrepreneur & 11 & \\
\hline & Housewife/ jobless & & \\
\hline
\end{tabular}

Table 2. Frequency distribution of respondents based on self-esteem.

\begin{tabular}{lccc} 
No & Self-esteem & Frequency & $(\%)$ \\
1 & Average & 19 & 39.6 \\
2 & High & 29 & 60.4 \\
\hline Total & 48 & 100 & \\
\hline
\end{tabular}

Table 3. Characteristics of respondents based on depression level.

\begin{tabular}{lccc} 
No & Depression Level & Frekuensi & $(\%)$ \\
1 & High & 1 & 2,1 \\
2 & Medium & 14 & 29,2 \\
\hline 3 & Mild & 33 & 68,8 \\
Total & 48 & 100 & \\
\hline
\end{tabular}


that the young must respect someone who is older. Based on the table of respondents who had a high school education were having high self-esteem (75\%). Educated people tend to have high self-esteem compared to uneducated respondents. ${ }^{6}$ Further, individuals with certain occupation had better self-esteem. ${ }^{7}$

\section{Depression level}

The results showed that most respondents had mild depression; it can be called as temporary depression, natural, a sense of pain in the process of change in thought of social communication and discomfort. Factors that influence depression among DM patients include gender and age, sex and marital status. ${ }^{8}$ Diabetes milletus is a chronic disease that cannot heal completely, needs lifelong care, can cause profound psychological changes in patients, also in their families and social groups. In patients who have been diagnosed with DM, there is an inadequate feeling, can be excessive, fear arises, they demand to be treated by others with excess, and hostility that might occur. This can also continue to be a feeling of depression in patients, depression in DM patients is quite high. In the case of DM, the physical consequences of chronic disorders (such as complications) place a limit, prohibiting individual lives. It aims to control blood sugar levels to remain normal and prevent unwanted consequences, in addition to controlling the DM in a long and complex period. ${ }^{9}$

In terms of age, it is shown in the results of the study that respondents who multiplied mild depression were mostly found in respondents aged $>35$ years (79.2\%). Respondents who experienced mild depression was found in respondents aged $>35$ years, based on the results of the research age of respondents on average 4045 years this is still relatively safe, in theory this depression will be heavier and even can become chronic when someone who is depressed is $>60$ years old. ${ }^{10}$

In terms of gender, it was found that respondents who experienced mild depression were mostly found in respondents with female gender as many as 24 respondents $(72.7 \%)$.

Based on the results of the study above there is no agreement between facts and theory, this is shown in the results of research that mild depression is mostly experienced by women, however, in theory it is said that cases of depression are more often experienced by women because of psychological factors that are quite weak, feelings and emotions are less stable than men.

\section{Relationship of self-esteem with depression level}

Based on the results of the Spearman rho statistical test, the Significant value $\varrho=$ $0.014<\alpha 0.05$ was obtained, it means that there was a correlation between self-esteem and depression level in Larangan Village, Krikilan Village, Driyorejo District, Kab. Gresik. High self-esteem influences positive social behavior while low selfesteem will have an unfavorable effect on individual behavior. Many problems arise because someone has low self-esteem. Low self-esteem tends to cause a person to behave less commendable because of a

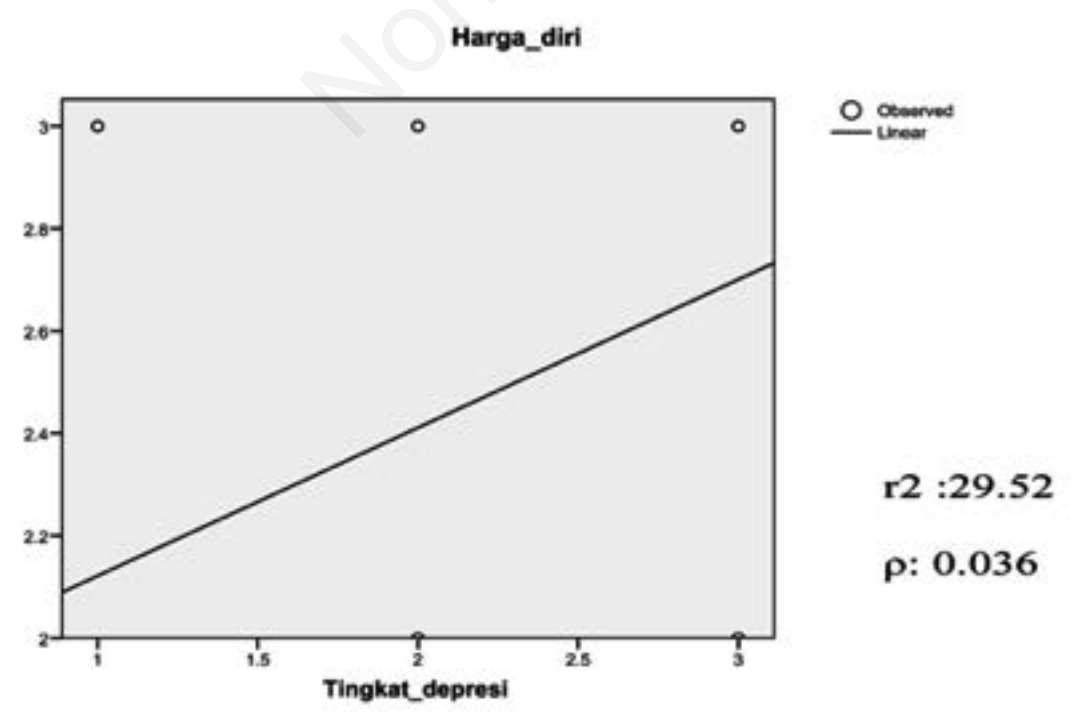

Figure 1. Linear Diagram of Relationship of Self-Esteem with Depression Level in People 200 with Diabetes Mellitus.

feeling of lack of confidence in his ability. Besides that low self-esteem can cause academic problems, appearance and social interaction, and can even cause depression. ${ }^{11}$ Depression is a sadness and prolonged grief or abnormal depression will inhibit the healing process, especially in controlling blood pressure. Efforts to overcome patients with depression are by creating a therapeutic environment, creating a pleasant environment, activating patients in various activities and motivating their actions, motivating patients to overcome problems, improving health status and increasing their self-esteem which can be expressed in positive attitudes of the relationship between self-esteem and depression, namely, the higher the level of self-esteem the lower the level of depression experienced by individuals suffering from diabetes mellitus. These statements tend to occur in patients with hypertension because diabetes mellitus and hypertension are chronic diseases and require a long-term treatment process. ${ }^{12}$

\section{Conclusions and suggestions}

The results of the Spearman Rho statistical test showed a Significant value $\mathrm{p}$ $=0.014<\alpha=0.05$, so it can be concluded that there is a relationship of self-esteem with the level of depression.

\section{References}

1. World Health Organization. Global status report on noncommunicable diseases 2010 Geneva: World Health Organization; 2010.

2. Kementerian Kesehatan Repubik Indonesia. Riset Kesehatan Dasar. Jakarta: Kementerian Kesehatan RI; 2013.

3. American Association of Diabetes Educators. AADE $7^{\mathrm{TM}}$ Self-Care Behaviors 2011. Available from: https://www.diabeteseducator.org/docs/d efault-source/practice/practiceresources/position-statements/aade7-self -care-behaviors-position-

statement.pdf?sfvrsn=6. Accessed on: 20 February 2018.

4. Malkowska-Szkutnik A, Gajewski J, Mazur J, et al. Self-esteem predictors in adolescents with diabetes. Med Wieku Rozwoj. 2012;16(1):35-46.

5. Bachman JG, O'Malley PM, FreedmanDoan P, et al. Adolescent Self-esteem: Differences by Race/Ethnicity, Gender, and Age. Self Identity 2011;10(4):44573.

6. de Araujo P, Lagos S. Self-esteem, education, and wages revisited. J Econ 
Psychol. 2013;34:120-32.

7. Housley K, Martin S, McCoy H, et al. Self-esteem of adolescent females as related to race, economic status, and area of residence. Percept Mot Skills 1987;64(2):559-66.

8. Carlock CJ. Enhancing self-esteem. 3rd ed. Washington, United States: Taylor \& Francis Inc; 1999.
9. American Diabetes Association. Diagnosis and classification of diabetes mellitus. Diabetes Care 2010; 33(Suppl 1):S62-S69.

10. Sartorius N. Depression and Diabetes. Dialogues Clin Neurosci. 2018;20(1): 47-52.

11. Bădescu SV, Tătaru C, Kobylinska L, et al. The association between Diabetes mellitus and Depression. J Med Life 2016;9(2):120-5.

12. Hypertension in Diabetes Study. Hypertension in Diabetes Study (HDS): II. Increased risk of cardiovascular complications in hypertensive type 2 diabetic patients. J Hypertens. 1993; 11(3):319-25. 